\title{
RNA-Binding Proteins as Targets to Improve Salt Stress Tolerance in Crops
}

\author{
Sara Rosa Téllez ${ }^{1,2,+}$, Rodoldphe Kanhonou ${ }^{1,2, \dagger}$, Carlos Castellote Bellés ${ }^{2,3}$, Ramón Serrano ${ }^{4}$, \\ Paula Alepuz ${ }^{2,3}$ and Roc Ros ${ }^{1,2, *(D)}$ \\ 1 Departament de Biologia Vegetal, Facultat de Farmàcia, Universitat de València, 46100 Burjassot (Valencia), \\ Spain; sara.rosa@uv.es (S.R.T.); Rodolphe.Kanhonou@uv.es (R.K.) \\ 2 Estructura de Recerca Interdisciplinar en Biotecnologia i Biomedicina (ERI BIOTECMED), Universitat de \\ València. 46100 Burjassot (Valencia), Spain; carloscastellotebelles@gmail.com (C.C.B.); \\ Paula.Alepuz@uv.es (P.A.) \\ 3 Departament de Bioquímica i Biologia Molecular, Facultat de Biologia, Universitat de València, 46100 \\ Burjassot (Valencia), Spain \\ 4 Instituto de Biología Molecular y Celular de Plantas (IBMCP), UPV-CSIC, 46022 Valencia, Spain; \\ rserrano@ibmcp.upv.es \\ * Correspondence: roc.ros@uv.es \\ + These authors contributed equally to this work.
}

Received: 19 December 2019; Accepted: 5 February 2020; Published: 8 February 2020

\begin{abstract}
Salt stress drastically reduce crop productivity. In order to identify genes that could improve crop salt tolerance, we randomly expressed a cDNA library of the halotolerant sugar beet in a sodium-sensitive yeast strain. We identified six sugar beet genes coding for RNA binding proteins (RBP) able to increase the yeast $\mathrm{Na}^{+}$-tolerance. Two of these genes, named Beta vulgaris Salt Tolerant 3 (BvSATO3) and BvU2AF35b, participate in RNA splicing. The other four BvSATO genes (BvSATO1, BvSATO2, BvSATO4 and BvSATO6) are putatively involved in other processes of RNA metabolism. $B v U 2 A F 35 b$ improved the growth of a wild type yeast strain under salt stress, and also in mutant backgrounds with impaired splicing, thus confirming that splicing is a target of salt toxicity. To validate the yeast approach, we characterized BvSATO1 in sugar beet and Arabidopsis. BvSATO1 expression was repressed by salt treatment in sugar beet, suggesting that this gene could be a target of salt toxicity. Expression of BvSATO1 in Arabidopsis increased the plant salt tolerance. Our results suggest that not only RNA splicing, but RNA metabolic processes such as such as RNA stability or nonsense-mediated mRNA decay may also be affected by salt stress and could be biotechnological targets for crop improvement.
\end{abstract}

Keywords: RNA-binding proteins; salt toxicity; sugar beet; yeast

\section{Introduction}

Global demand for food production is increasing and will continue to increase over the next several decades. Drought and salinity stresses are considered the two major abiotic stresses that drastically reduce the productivity in cultivated plants, threatening food security [1-3]. This is because crop plants are very sensitive to high $\mathrm{NaCl}$ concentrations in soil and water, which produces water deficit, ion toxicity, nutrient imbalance and oxidative stress [2,4-7]. Furthermore, high temperatures associated to climate change are increasing evapotranspiration rates, which will exacerbate the problem of culture salinization in the next decades. Thus, one of the big challenges of agrobiotechnology is to develop crops better adapted to salt stress.

The adaptation mechanisms to salt stress require the activity of effector molecules that lead to tolerance (transport systems that re-establish ion homeostasis, metabolites that confer osmotic 
adjustment, detoxifying enzymes and components of biochemical pathways), and also regulatory proteins that control the amount and timing of these effector molecules [7-9]. Extensive molecular and genetic analysis has led to the identification of some of the components involved in salt stress tolerance. These include, the so-called SOS pathway, a regulatory pathway for ionic homeostasis [10-12], components of the abscisic acid (ABA)-dependent and -independent osmotic stress signaling [13-18], several sodium transporters, protein kinases, enzymes and transcription factors [10,19-24]. These studies have started to generate practical results and the genetic engineering of plant salt tolerance is giving promising results [3,25-28]. However, the understanding of the complex mechanisms of plant adaptation to salt stress is far from complete. More specifically, information about targets of salt toxicity in plant cells is scarce. One of the adaptation mechanisms of plants to salt stress implies compartmentation at the organ level (roots vs shoots) but also at the intracellular level (vacuoles vs cytoplasm). It has been suggested that non-halophytes are usually exposed to excess ions in leaves or expanding tissues which could also be associated with an accumulation of these ions in leaf cell cytoplasms due to an inadequate compartmentation at both cellular and organ level [29]. For that reason, the search of potential targets of salt toxicity in leaves could be a strategy to improve salt tolerance in glycophytic crops.

Many cultivated plants including fruit trees (citrus, avocado, stone fruits) and cereals (beans and barley) are very sensitive to salt stress and thus are considered glycophytic species. Sugar beet is a crop with halophytic ancestors such as Beta vulgaris ssp. Maritima, which is found in salt marshes in association with Atriplex hastata and Suaeda fructicosa [29]. In fact, concentrations higher that $250 \mathrm{mM}$ monovalent salts in soils are required to produce a 50\% reduction in sugar beet yield as compared to for example beans, where only $60 \mathrm{mM}$ is required. Thus, sugar beet could be a potential source of halotolerant genes for glycophytic crop plants. We previously followed a strategy based on random expression of sugar beet genes in the yeast model system that allowed us to identify several sugar beet halotolerance genes, such as the catalytic subunit of the protein kinase CK2 [30] or the translation initiation factor eIF1A [31]. We also identified several RNA-binding proteins (RBP) that conferred tolerance to yeast [32]. In eukaryotes, RBPs are involved in several steps of mRNA metabolism such as splicing, capping, polyadenylation, transport, regulation of mRNA stability and mRNA translation [33]. RBP are characterized by the presence of functional motifs and domains, with the RNA recognition motif (RRM) and $\mathrm{K}$ homology domain being the most common in plants [34]. Other domains and motifs include the Tudor-SN domain, serine/arginine repeats (SR), glycine/arginine-rich domains (GR), zinc finger domains, and cold shock domains [35-38]. In the Arabidopsis genome, more than 200 RBP have been identified, being most of them plant specific, and therefore likely to perform plants-specific functions [33,34,37]. In fact, some RBP are emerging as key processes participating in the cellular responses to stress [34,38-44] and some of them has specifically been involved in the plant response to salinity [42,44-47]. In this work, we describe the characterization of several sugar beet RBPs identified by random expression in yeast that could be important targets of salt toxicity in plants.

\section{Materials and Methods}

\subsection{Plant Material, Yeast Strains and Culture Conditions}

Sugar beet plants (Beta vulgaris cv. DITA) were grown in greenhouse as previously described [30]. This cultivar was selected for its high $\mathrm{NaCl}$ tolerance, after growing different cultivars in increasing concentrations of $\mathrm{NaCl}$ and comparing their salt tolerance to the will type ancestor Beta maritima. For the construction of the cDNA library, three-week-old plants were irrigated with $200 \mathrm{mM} \mathrm{NaCl}$ for $24 \mathrm{~h}$ before harvesting. For the Northern blot analysis, three-week old sugar beet plants were irrigated with or without $250 \mathrm{mM} \mathrm{NaCl}$ and plant organs were harvested at different time points, as indicated. For Southern blot analysis three-week old sugar beet leaves were used.

Arabidopsis thaliana plants (ecotype Columbia) were used to obtain transgenic plants expressing BvSATO1. For salt tolerance experiments, Arabidopsis plants were grown in greenhouse conditions 
in pots containing a mixture of vermiculite and peat $(1: 2, \mathrm{~V}: \mathrm{V})$. Twenty-five seeds of wild type and transgenic Arabidopsis plants were grown in $750 \mathrm{~mL}$ pots that where irrigated biweekly with nutrient solution containing $50 \mathrm{mM} \mathrm{NaCl}$. Control plants were irrigated with a nutrient solution without $\mathrm{NaCl}$ supplementation.

The Saccharomyces cerevisiae strain JM26 (MATa leu 2-3,112 ura 3-1 trp1-1, ade 2-1 his3-11,15 can 1-100, ena 1-4::HIS3, nha1::TRP1) provided by Dr. J.M. Mulet was used for the screening of the sugar beet cDNA library and characterisation of the RBP cDNA clones. Strain JM26 is a derivative of W303.1A [48] with null mutations of the genes ENA 1-4 and NHA1, encoding a Na${ }^{+}$-pumping ATPase and a $\mathrm{Na}^{+} / \mathrm{H}^{+}$ antiporter, respectively, responsible for most of the yeast sodium extrusion $[49,50]$. This strain was named ena 1-4 nha1.

Yeast strains for checking salt stress tolerance were the wild-type BY4741 (MATa his $3 \Delta 1$ leu2 $\Delta 0$ met $15 \Delta 0$ ura $3 \Delta 0$ ) and the derived mutants mud2 $2:: \operatorname{KanMX} 4$ and cus $2 \Delta:: K a n M X 4$ from the Saccharomyces cerevisiae gene disruption EURSCARF collection [51].

Yeast were grown in minimal synthetic glucose medium (SD) or complete glucose medium (SC). SD medium contained $2 \%$ glucose, $0.7 \%$ yeast nitrogen base without amino acids and $50 \mathrm{mM}$ succinic acid, adjusted to $\mathrm{pH} 5$ with Tris, $2 \%$ bacteriological-grade agar, plus the required auxotrophies [100 $\mu \mathrm{g} / \mathrm{mL}$ leucine (L), $30 \mu \mathrm{g} / \mathrm{mL}$ adenine (A)]. SC medium contained $2 \%$ glucose, $0.7 \%$ yeast nitrogen base without amino acids and the required drop-out mix (Formedium, Hunstanton, UK), plus the required auxotrophies $(100 \mu \mathrm{g} / \mathrm{mL} \mathrm{L}(\mathrm{L}), 30 \mu \mathrm{g} / \mathrm{mL}$ A) [52].

The growth of yeast cells under different stress conditions was assayed after cells were grown at $30^{\circ} \mathrm{C}$ till early log phase (OD600 0.2-0.3) in SC-ura or SD-ura by spotting serial dilutions (1:10, 1:100, $1: 1000,1: 10,000)$ on plates with the indicated salt concentrations.

\subsection{Construction of the Sugar Beet cDNA Library Induced by Salt Stress and Isolation of cDNA Clones conferring Salt Tolerance to Yeast}

Directional cDNAs were synthesised as already described [30] and incorporated into the expression plasmid pYPGE15 (URA3 as a selection marker) that may be directly used for both E. coli and yeast complementation [53].

To screen for sugar beet cDNAs that increase salt tolerance in yeast, the cDNA library constructed in pYPGE15 was used to transform the yeast mutant strain ena 1-4 nha1 by the LiCl method [54]. Transformants selected on SD with L and A plates (SDAL) by uracil prototrophy were pooled and replated on screening medium (SDAL + methionine supplemented with $0.15 \mathrm{M} \mathrm{NaCl}$ ) at a density of $2 \times 10^{5}$ cells per plate $(12 \times 12 \mathrm{~cm})$. The putative positive clones were rescreened on the same $\mathrm{NaCl}$ medium. The plasmids contained in these pYPGE15 clones were isolated and reintroduced into JM26 cells to confirm that it conferred salt tolerance. Selection against the URA3-marked plasmid using 5-fluoroorotic acid restored the salt sensitivity of the yeast cells. The inserts of pYPGE15 were sequenced using a DNA sequencer (Model ABI 377, PE Biosystems, Foster City, Ca, USA) and those with unknown names in other organisms were called SATO, from Salt Tolerance. Six of the confirmed clones, coded for RBP. The GeneBank or NCBI accession number of all sugar beet cDNAs identified in this work is included in Table 1. 
Table 1. Sugar beet halotolerance genes identified by expression in the salt sensitive yeast mutant ena 1-4 nha1. The E value describes the number of expected hits of similar quality (score) that could be found just by chance.

\begin{tabular}{|c|c|c|c|c|c|c|c|c|}
\hline Gene Name & $\begin{array}{l}\text { GenBank or NCBI } \\
\text { Accession Number }\end{array}$ & $\begin{array}{l}\text { Times } \\
\text { Isolated }\end{array}$ & $\begin{array}{l}\text { Amino } \\
\text { Acids }\end{array}$ & $\begin{array}{l}\text { RNA Binding } \\
\text { Motifs }\end{array}$ & $\begin{array}{l}\text { Homologs in } \\
\text { Arabidopsis }\end{array}$ & $\begin{array}{c}\text { Yeast } \\
\text { Homologues }\end{array}$ & $\begin{array}{c}E \\
\text { Value }\end{array}$ & Predicted Functions \\
\hline BvSATO1 & CAC85227.1 & 6 & 356 & RGG, RE, RD & $\begin{array}{l}\text { At4g16830 } \\
(\text { AtRGGA) }\end{array}$ & - & - & $\begin{array}{l}\text { RNA stability, storage or } \\
\text { translation }\end{array}$ \\
\hline BvSATO2 & XP_010677113.1 & 1 & 356 & RGG, RE, RD & $\begin{array}{l}\text { At4g16830 } \\
(\text { AtRGGA) }\end{array}$ & - & - & $\begin{array}{l}\text { RNA stability, storage or } \\
\text { translation }\end{array}$ \\
\hline BvSATO3 & CAC 85244.1 & 1 & 342 & $\begin{array}{l}\text { Pro-rich, } \\
\text { Zn-finger }\end{array}$ & $\begin{array}{l}\text { At5g51410 } \\
\text { (AtLuc7) }\end{array}$ & $L u c 7 p$ & $\mathrm{E}-20$ & $\begin{array}{l}\text { U1 snRNA associated protein. } \\
\text { Involved in Splicing }\end{array}$ \\
\hline BvSATO4 & XP_010673688.1 & 1 & 203 & RRM & $\begin{array}{c}\text { At1g51510 } \\
(\text { AtY14) }\end{array}$ & Rna15p & E-6 & $\begin{array}{l}\text { Member of the exon junction } \\
\text { complex: Intron mediated } \\
\text { enhanced gene expression, } \\
\text { nonsense-mediated mRNA decay }\end{array}$ \\
\hline BvSATO6 & CAC85246.1 & 1 & 323 & Three RRM & $\begin{array}{l}\text { At1g11650 } \\
(\text { AtRBP45) }\end{array}$ & Nam $8 p$ & E-50 & RNA stability \\
\hline$B v U 2 A F 35 b$ & XP_010683884.1 & 3 & 310 & $\begin{array}{l}\text { RRM, Two } \\
\text { Zn-finger }\end{array}$ & $\begin{array}{c}\text { At5g42820 } \\
(A t U 2 A F 35)\end{array}$ & - & - & $\begin{array}{l}\text { U2 snRNA associated protein. } \\
\text { Involved in splicing }\end{array}$ \\
\hline
\end{tabular}




\subsection{Cloning of BvSATO1 and Plant Transformation}

The binary Ti vector pBI121 was used for transformation [55]. An insert of $1370 \mathrm{bp}$ containing the BvSATO1 cDNA was obtained by digesting pYPGE15-BvSATO1 with BamH I and EcoR V (blunt ends). This insert was directionally cloned between the BamH I-blunt end sites of pBI121 previously digested with BamH I-Ec1136 II. This construct, named pBI121-BvSATO1, was electroporated into the Agrobacterium tumefaciens strain C58C1 [56]. Agrobacterium mediated transformations were performed by the floral dipping method [57] and transgenic selection was performed as previously described [31]. Homozygous lines ( $T_{3}$ generation) from ten independent transformants were obtained. We chose two lines with high levels of transgene expression for phenotypic characterisation.

\subsection{Southern Blot and RNA Expression Analysis}

Southern and northern blot analysis from sugar beet genomic DNA and mRNA was performed as indicated [30]. To analyse cellular mRNA levels in the mutant yeast strain ena 1-4 nha1 expressing $B v U 2 A F 35 b$ and BvSATO1, exponentially growing cultures were incubated under the salt conditions and at the times indicated, and 20-mL cells culture were collected by centrifugation and frozen at $-20^{\circ} \mathrm{C}$. Total RNA was extracted and retrotranscribed as described in Garre et al. [58]. mRNA levels of STL1 and GPD1 were examined using specific primers (3-STL1-3c F: 5'CCGGAAGAAGTTTGGAGG AA $3^{\prime}$ and 3-STL1-5b R: 5'CTCAACGATTGGTAAACG 3' for STL1 and 3-GPD1-3 F: 5'TTCTGCTGC CATCCAAAGAG 3' and 3-GPD1-5 R: 5'GAGACAGCTTCTGAAGGGTA $3^{\prime}$ for detection of GPD1) and normalized to the levels of $A C T 1$ used as reference gene (M1-ACT1 F: 5'TCGTTCCAATTTACGCTGGTT $3^{\prime}$ and M2-ACT1 R: 5'AACTCTTAGCTAAACCGGC 3').

\section{Results}

\subsection{Isolation and Molecular Characterisation of Sugar Beet Genes Conferring Salt Tolerance to Yeast}

In order to identify molecular targets of salt toxicity in plants, we constructed a $\mathrm{NaCl}$-induced cDNA expression library from the aerial part of sugar beet plants, and undertook a systematic search for genes that confer increased salt tolerance when expressed in the $\mathrm{Na}^{+}$-sensitive yeast strain ena 1-4 nha1. After transforming 100.000 individual cells with the plasmid pYPGE15 containing the cDNA inserts, colonies were pooled and selected for their ability to grow in the presence of $150 \mathrm{mM} \mathrm{NaCl}$ plus methionine in a stepwise selection procedure. Methionine was added to the medium to avoid selection of the HAL2-like homologs already identified in Arabidopsis [52]. The yeast HAL2 gene encodes a $\mathrm{Li}^{+} / \mathrm{Na}^{+}$sensitive phosphatase that participates in sulfate assimilation. Concretely, HAL2 is involved in the degradation of the toxic by-product adenosine $3^{\prime} 5^{\prime}$-bisphosphate. HAL2 inhibition by $\mathrm{Na}^{+}$ and $\mathrm{Li}^{+}$critically affects yeast growth. Supplementation with methionine, the end product of sulfate assimilation, suppresses the toxic effects of $\mathrm{Li}^{+} / \mathrm{Na}^{+}$associated to HAL2 inhibition because the sulfate assimilation is blocked and no adenosine $3^{\prime} 5^{\prime}$-bisphosphate is accumulated. This strategy allowed us to identify gene targets of salt toxicity other than HAL2 [30,31]. Six out of the eleven halotolerant genes isolated coded for proteins with typical RNA-binding motifs in their amino acid sequences such as the RRM, RGG or RD/RE/RS (Table 1). One of these proteins is homolog to the splicing factor U2 auxiliary factor (U2AF) small subunit b (AtU2AF35b) from Arabidopsis [59], and we named it BvU2AF35b. The other five proteins identified were named BvSATO1-4 (from Beta vulgaris salt tolerance) and BvSATO6.

A southern blot analysis was performed in order to confirm the presence of BvSATO genes in the sugar beet genome (Supplemental Figure S1). Accordingly, we found in the available Beta vulgaris genome database (Beta vulgaris ssp. vulgaris; http://bvseq.boku.ac.at/, https://blast.ncbi.nlm.nih. gov/) [60] that BvSATO1 is located in the chromosome 1, and has an analog (60\% identity at the amino acid level) located in chromosome 5, which also appeared in our screening (BvSATO2). BvSATO3 is located in chromosome 3 and could have different spliced isoforms. BvSATO4 is located in chromosome 4 and do not have close analogs. BvSATO6 is located in chromosome 8 and have and analog with a percentage of amino acid identity higher than $60 \%$. Finally, BvU2AF35b is located in chromosome 7 
and have a close analog with a percentage of amino acid identity higher than $75 \%$. BvSATO3, BvSATO4 and BvSATO6 have close related yeast homologs while BvU2AF35b, BvSATO1 and BvSATO2 do not have close homologs in this species (Table 1).

We confirmed that the expression of RNA-binding sugar beet genes increased the yeast tolerance not only to $\mathrm{Na}^{+}$but also to $\mathrm{Li}^{+}$in the ena 1-4 nha1 background (Figure 1A,B). Besides, this tolerance phenotype was observed both in the presence and absence of methionine in the growth medium (Figure 1A,B). As stated, BvSATO1, BvSATO2 and BvU2AF35b did not show a close homology with yeast genes. In order to support the functional significance of BvSATO1 and BvU2AF35b in yeast, we investigated whether their expression could also increase the yeast tolerance in a wild-type strain, not only in a laboratory strain. As showed in Figure 2, both BvSATO1 and BvU2AF35b expression were able to increase the tolerance to $\mathrm{Na}^{+}$and $\mathrm{Li}^{+}$in a wild-type genetic background, confirming that functions performed by these proteins could be important determinants of salt tolerance in this organism.

A

SDAL

SDAL

$+200 \mathrm{mM} \mathrm{NaCl}$

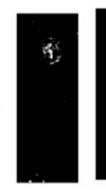

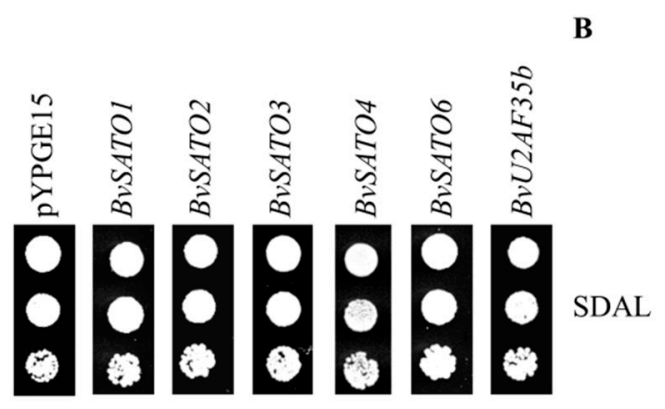
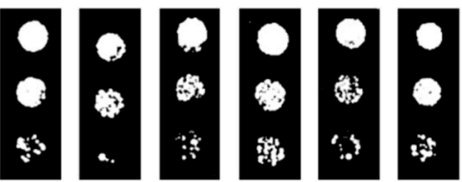

SDAL

$+5 \mathrm{mM} \mathrm{Li}$
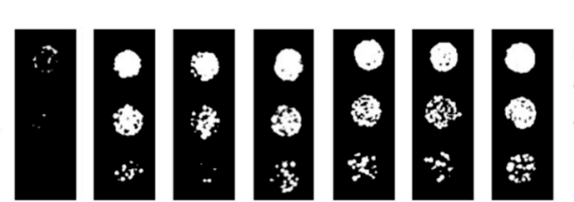

SDAL

$+50 \mathrm{mM} \mathrm{Li}$

+ Met

+ Met

i.

政
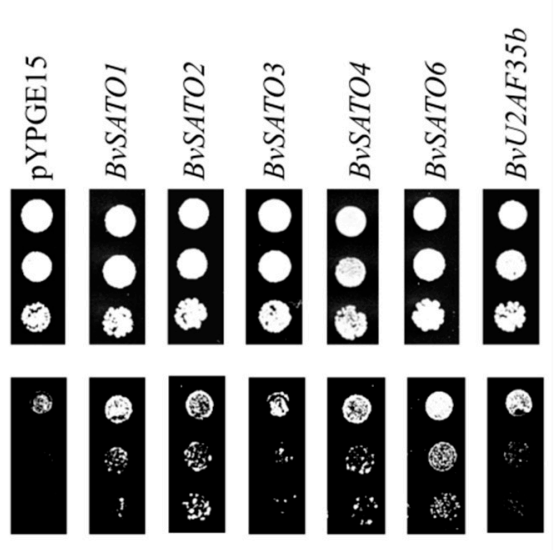

Figure 1. Sodium (A) and lithium (B) tolerance phenotype of ena 1-4 nha1 yeast cells expressing the sugar beet RNA binding proteins. ena 1-4 nha1 cells were transformed with either the empty vector (pYPGE15) or pYPGE15 containing the cDNA of the RNA binding proteins. Transformed cells were tested for tolerance to different concentrations of sodium and lithium, and in the presence or absence of methionine, as indicated in the figures. Spots show serial dilutions of yeast growth, as described in materials and methods. Images of cells grown in control media (SDAL) were taken after two days of growth. Images of cells grown in other media were taken between three and seven days of growth depending on the salt concentration. 


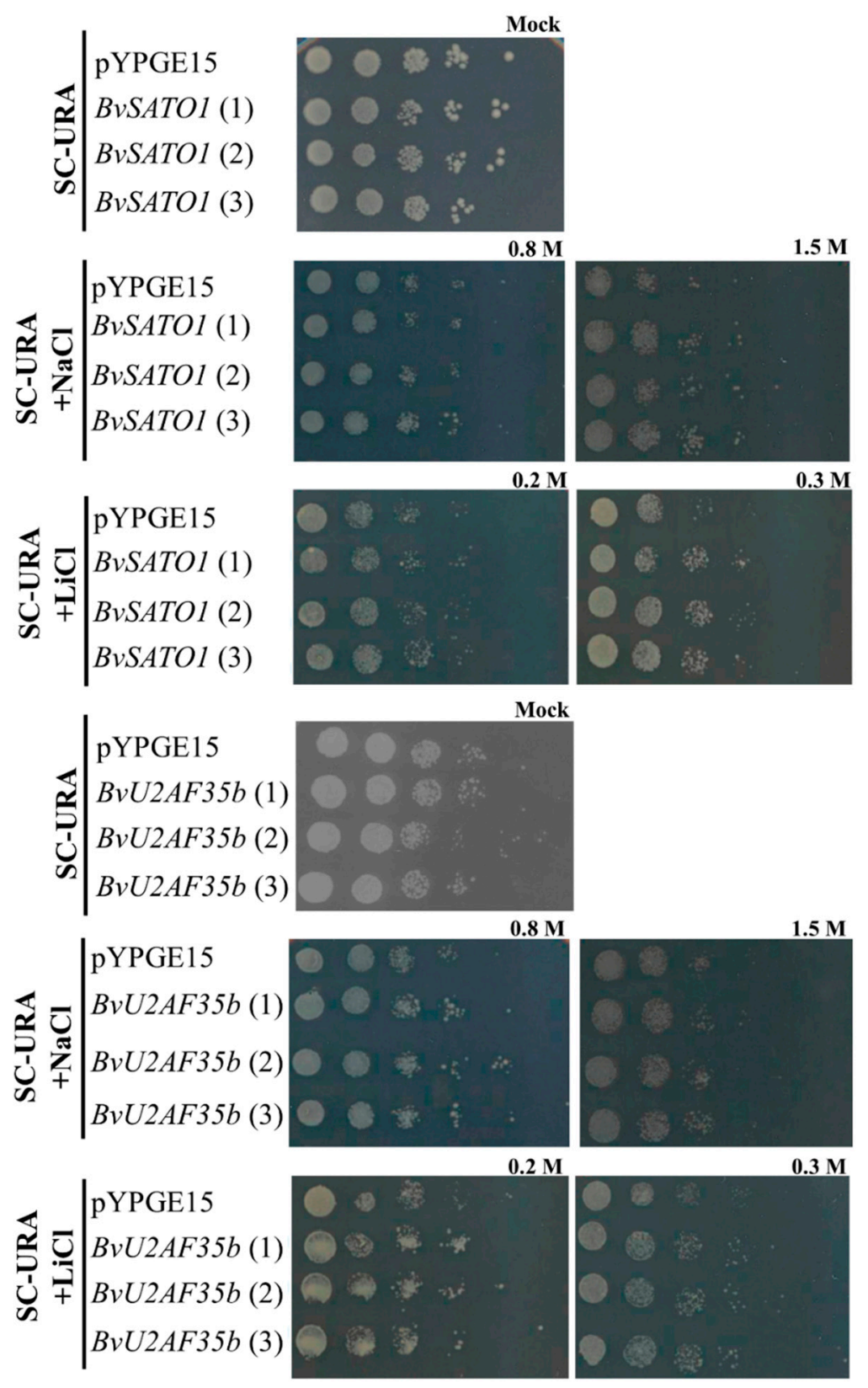

Figure 2. Sodium and lithium tolerance phenotype of wild-type yeast cells expressing the sugar beet RNA binding proteins BvSATO1 and BvU2AF35b. Wild-type yeast cells were transformed with either the empty vector (pYPGE15) or pYPGE15 containing the cDNA of BvSATO1 or BvU2AF35b. Transformed cells were tested for tolerance to different concentrations of sodium and lithium as indicated in the figures. Spots show serial dilutions of yeast growth, as described in materials and methods. Images of cells grown in control media (SC) were taken after two days of growth. Images of cells grown in other media were taken between three and seven days of growth depending on the salt concentration.

\subsection{BvU2AF35b Improves Growth of Yeast Mutants with Impaired Splicing under Salt Stress}

Two of the sugar beet genes improving yeast growth under salt stress, code for proteins whose orthologs in other organisms participate in splicing. We choose BvU2AF35b, isolated three times in the screening, to investigate if it could improve the growth of mutants impaired in splicing. In mammals and plants, the U2AF is a heterodimer formed by a large (U2AF65) and small (U2AF35) subunits, which participate along with the $\mathrm{U} 2$ small nuclear ribonucleoprotein particle (U2snRNP) 
in the recognition of the $3^{\prime}$ splice site during splicing. The large subunit U2AF65 has homologs in yeast, but the small subunit U2AF35 is not present as such in the yeast spliceosomal complex. Instead, a single protein called MUD2 (homolog to U2AF65) is considered the yeast functional homolog of the plant U2AF65/U2AF35 heterodimer, binding early during spliceosome assembly to recognize the branch point sequence and bridges the subsequent binding of U2 snRNP complex [61,62]. A search in the yeast genome database (https://www.yeastgenome.org/) identified other yeast splicing proteins which could have functional homologies with BvU2AF35b. One of them, CUS2 is also a subunit of the yeast U2snRNP complex and has motifs homologous to BvU2AF35b. In order to investigate whether BvU2AF35b could improve splicing under salt stress, we expressed BvU2AF35b in the mutant yeast strains cush $2 \Delta$ and $m u d 2 \Delta$. BvU2AF35b expression improved the growth of both mutant strains in the presence of $1.5 \mathrm{M} \mathrm{Na}^{+}$(Figure 3 and Supplemental Figure S2) indicating that it can improve yeast splicing under salt stress.

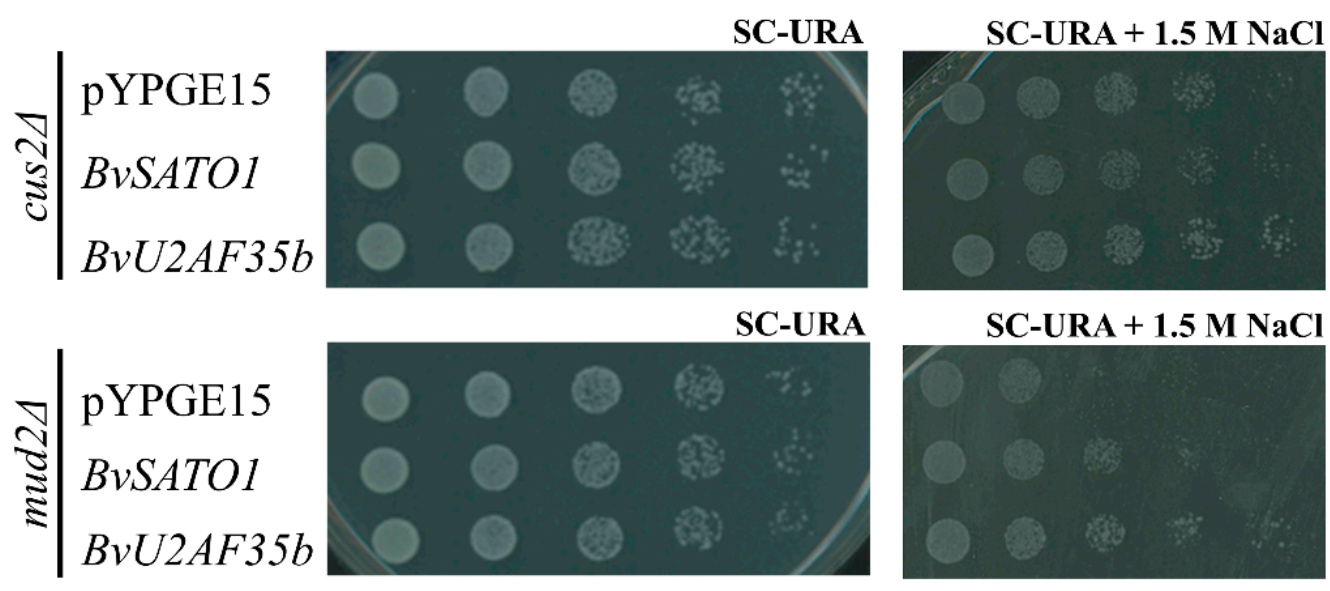

Figure 3. Sodium tolerance phenotype of yeast mutants impaired in splicing when expressing the sugar beet RNA binding proteins BvSATO1 and BvU2AF35b. cus $2 \Delta$ and mud2 $\Delta$ mutants were transformed with either the empty vector (pYPGE15) or pYPGE15 containing the cDNA of BvSATO1 or BvU2AF35b. Transformed cells were tested for tolerance to sodium. Spots show serial dilutions of yeast growth, as described in materials and methods. Images of cells grown in control media (SC) were taken after two days of growth. Images of cells grown in $1.5 \mathrm{M} \mathrm{NaCl}$ were taken seven days later.

\subsection{BvU2AF35b Increases the Expression of Genes Related to the Response to Osmotic Stress in Yeast}

A time-course gene expression kinetic was run to investigate whether the improved growth observed in yeast lines expressing BvU2AF35b and BvSATO1 could be correlated with a higher induction of genes known to respond to osmotic stress. For that purpose, the yeast strain ena 1-4 nha1 expressing $B v U 2 A F 35 b$ or BvSATO1 was grown in control medium or medium with $0.2 \mathrm{M} \mathrm{NaCl}$, and samples were collected at 0,15 and 30-min time points. The yeast expression kinetics under osmotic stress peak between 15 and $30 \mathrm{~min}$ after the osmotic shock is applied. By taking samples at these two time points we assured that the expression peak was recorded. The expression STL1 was higher in ena 1-4 nha1 expressing BvU2AF35b than in controls at both 15 and 30 min after the $\mathrm{NaCl}$ treatment (Figure 4). GPD1 expression was also higher in ena 1-4 nha1 expressing BvU2AF35b than in controls 30 min after the salt treatment. Induction of genes related to osmotic stress was not different to that of controls when expressing BvSATO1 (Figure 4) suggesting that the mechanism of growth improvement conferred by $B v S A T O 1$ under salt stress is different from that of BvU2AF35b. 

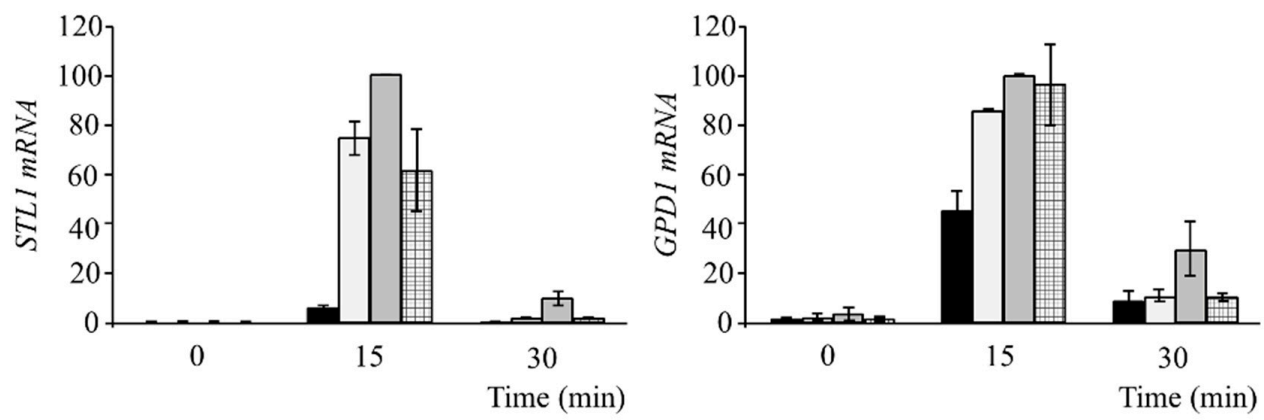

Figure 4. Effect of expression of BvSATO1 and BvU2AF35b on the expression of genes related to the response to osmotic stress in yeast. Expression of genes STL1 and GPD1 was measured at two time points (15 and $30 \mathrm{~min}$ ) after treating with $0.2 \mathrm{M} \mathrm{NaCl}$ wild-type (WT), and ena 1-4 nha1 cells transformed with either the empty plasmid (pYPGE15) or pYPGE15 containing the cDNA of BvSATO1 or BvU2AF35. Values represent the mean \pm SD of three independent determinations.

3.4. BvSATO1 Is Repressed by Salt Treatment in Sugar Beet and Its Expression in Arabidopsis Increases Salt Tolerance

BvSATO1 is not described as participating in splicing and do not have clear homologs in yeast. However, BvSATO1 was the gene isolated more times in the yeast screening, and the homolog BvSATO2 was also isolated (Table 1). Because of that, we further characterized these genes in sugar beet and Arabidopsis.

The analysis of BvSATO1 and BvSATO2 expression showed that these two genes are expressed in all the studied sugar beet organs (leaves, cotyledons, stems and roots, Figure 5). BvSATO1 and BvSATO2 expression was not induced by salt stress in the assayed conditions (Figure 5). Rather, a repression was observed by salt treatment at different times in all studied organs (Figure 5). BvSATO1 and BvSATO2 expression was also not induced by ABA in leaves and cotyledons in the conditions tested (Figure 6).

A.

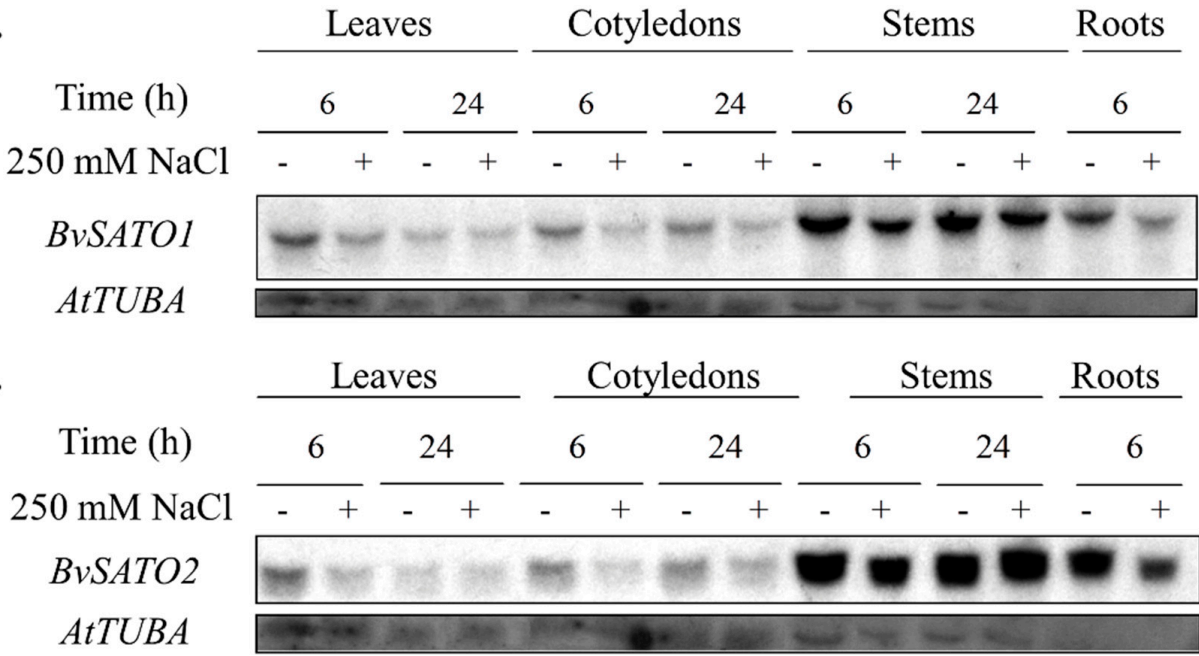

Figure 5. Expression analysis of BvSATO1 and BvSATO2 in sugar beet organs with or without salt stress treatment $(250 \mathrm{mM} \mathrm{NaCl}$ for 6 or $24 \mathrm{~h})$. Whole RNA was isolated from sugar beet treated and not treated plants, separated on an agarose gel, transferred to a nylon membrane and hybridized with a BvSATO1 radiolabeled probe (A, upper panel), or a BvSATO2 radiolabeled probe (B, upper panel). In the lower panels of $\mathrm{A}$ and $\mathrm{B}$ the same RNA blot was hybridized with a tubulin probe (AtTUBA accession number M17189) as loading control. 
A.
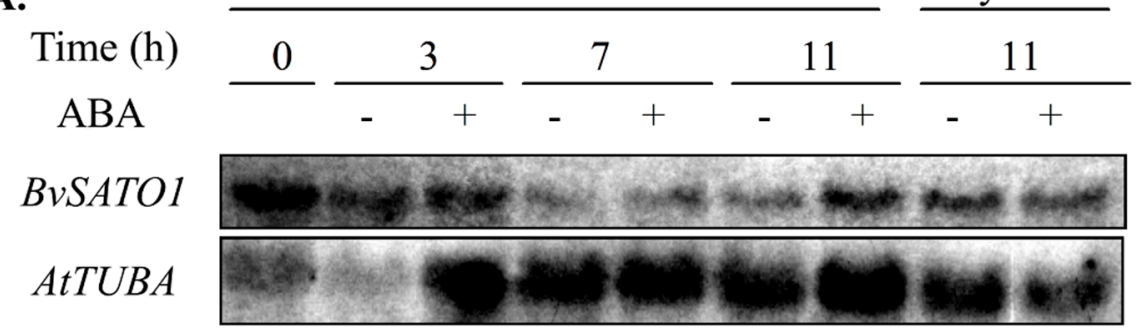

B.

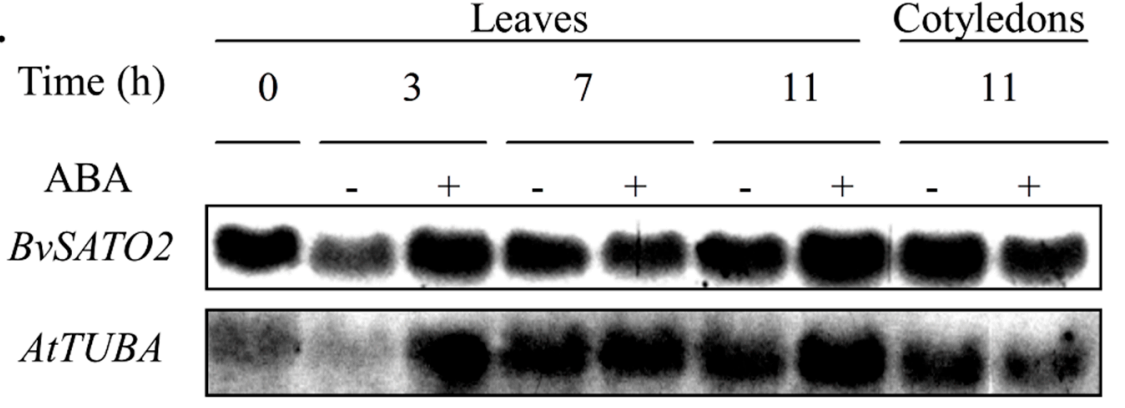

Figure 6. Effect of ABA on BvSATO1 and BvSATO2 expression in sugar beet leaves and cotyledons. Whole RNA was isolated from sugar beet leaves and cotyledons treated and not treated with ABA, separated on an agarose gel, transferred to a nylon membrane and hybridized with a BvSATO1 radiolabeled probe (A, upper panel), or a BvSATO2 radiolabeled probe (B, upper panel). In the lower panels of A and B the same RNA blot was hybridized with a tubulin probe (AtTUBA accession number M17189) as loading control.

As a proof-of concept to validate the yeast approach we overexpress the sugar beet BvSATO1 in Arabidopsis. We obtained ten BvSATO1 expressing lines (Figure 7) and selected two with high BvSATO1 expression level (lines 9 and 11) for phenotypic characterization under salt stress conditions. BvSATO1 expression improved the growth of Arabidopsis plants in the presence of $50 \mathrm{mM} \mathrm{NaCl}$ (Figure 8A,B). The percentage of plants reaching the reproductive stage was higher in both BvSATO1 expressing lines as compared to controls (Figure 8B). Also, there was a trend to an increase in the shoot weight of BvSATO1 expressing lines that was significant in one of them (Figure 8C), confirming that BvSATO1 confers and advantage to Arabidopsis when grown under salt stress conditions.

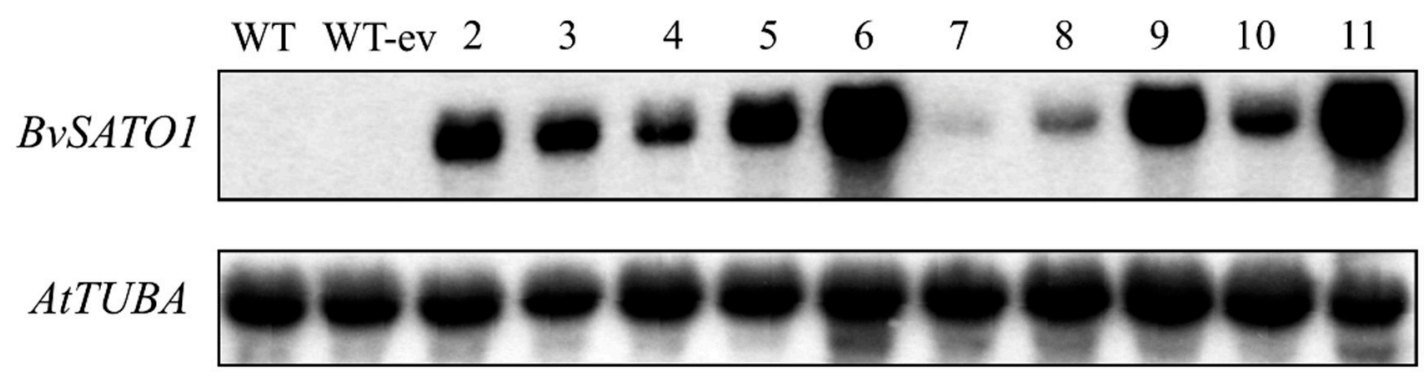

Figure 7. BvSATO1 expression analysis in ten Arabidopsis transgenic plants (lines 2-11). Whole RNA was isolated from Arabidopsis transgenic plants expressing BvSATO1, from wild-type plants (WT) and from wild-type plants expressing the empty plasmid (WT-ev). As loading control, the expression of the AtTUBA is shown in the lower panel. 
$\mathbf{A}$

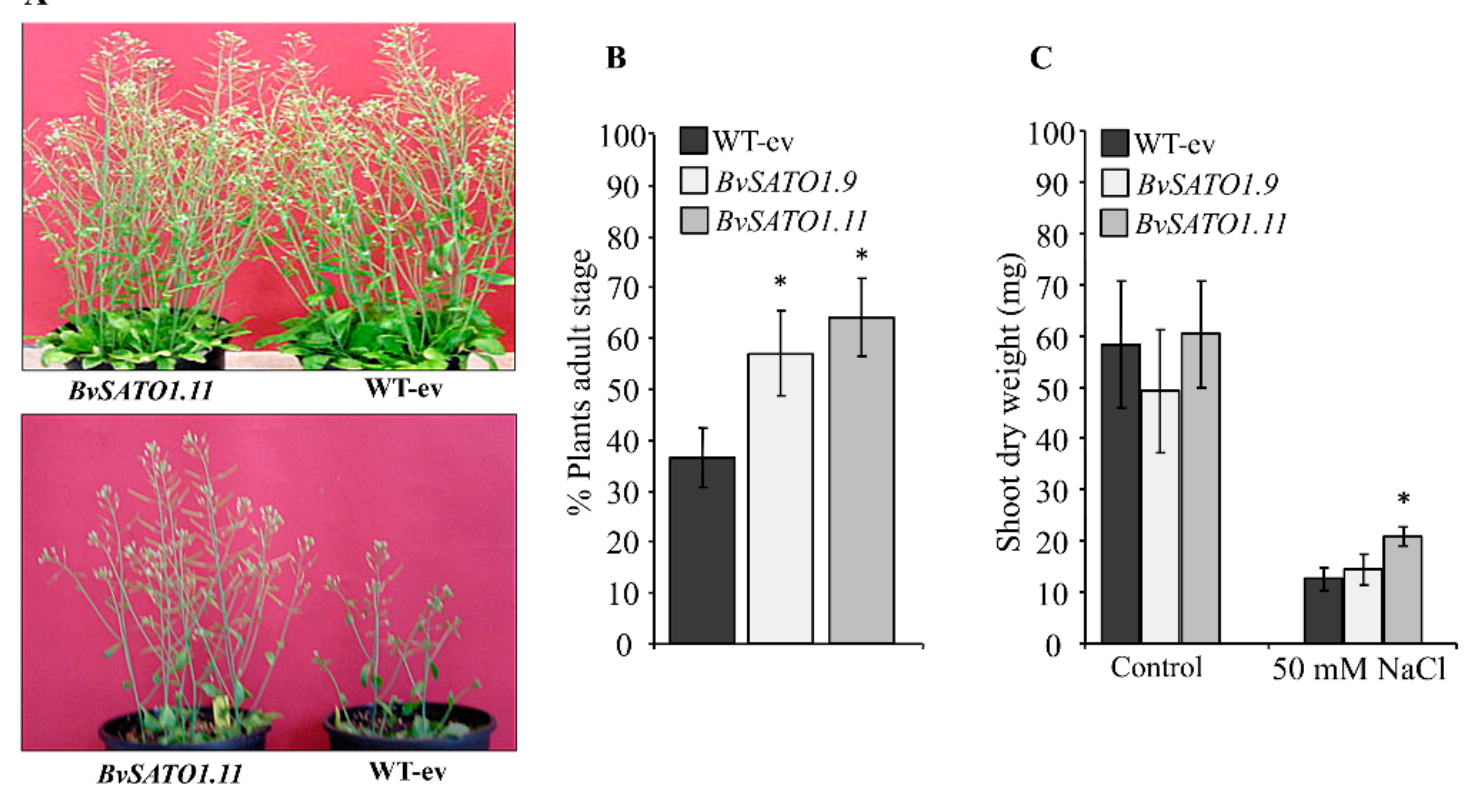

Figure 8. Salt tolerance phenotype of Arabidopsis plants expressing BvSATO1. A. Image of wild-type transformed with the empty vector (WT-ev) and transgenic plants expressing BvSATO1, grown in a control media (upper panel) or in a media supplemented with $50 \mathrm{mM} \mathrm{NaCl}$ (lower panel). B. Percentage of plants reaching the reproductive stage in $\mathrm{NaCl}$ as compared to control media. C. Shoot dry weight in control and in media supplemented with $50 \mathrm{mM} \mathrm{NaCl}$. Values represent the mean $\pm \mathrm{SE}$ of four independent determinations ( $n>100$ plants for each determination). * Significantly different to WT-ev $(p<0.05)$.

\section{Discussion}

Expression of sugar beet genes increased tolerance of the yeast mutant ena 1-4 $\mathrm{nha}$ to $\mathrm{Li}^{+}$and $\mathrm{Na}^{+}$but also of the wild-type strain, indicating that proteins coded by these genes could improve bottle neck mechanisms of salt tolerance in this species. Two of the proteins identified code for putative splicing factors, which points to this process as a target of salt toxicity. Following a similar approach, Forment et al. [45] identified several splicing factors (a component of the U1-snRNP and two arginine-rich proteins) that increased yeast tolerance upon expression [63]. It was concluded that pre-mRNA splicing could play an important role in the salt tolerance of eukaryotic cells. In our screening we identified BvSATO3, which is ortholog of the Arabidopsis U1snRPN accessory protein LUC7. It has been demonstrated that LUC7 is important for constitutive splicing, but also for alternative splicing events modulated by stress [42]. We also identified a second protein, BvU2AF35b, known to participate in mRNA splicing in plants and mammals. Arabidopsis plants with reduced levels of U2AF35b displayed late flowering phenotypes, which was associated with abnormal splicing patterns of gene Flowering Control Locus A ( $F C A$ ) and increased expression of the flowering repression gene Flowering Locus C (FLC) [59]. Arabidopsis mutants of the large U2AF subunit (AtU2AF65b) showed, however, early flowering which was associated with reduced expression of FLC [64]. These authors demonstrated that the reduced transcription of FLC was partially due to the abnormal splicing of ABCISIC ACID INSENSITIVE 5 (abi5) which regulates flowering in an ABA-dependent signaling mechanism. The fact that AtU2AF65b can regulate ABA signaling may suggest that other ABA dependent responses, such as salt stress, could also be regulated by this splicing factor in plants.

BvSATO4 is orthologue of the Arabidopsis AtY14, a member of the exon junction complex (EJC) [65]. The EJC has been involved in several processes related to mRNA metabolism, from splicing, mRNA transport or even translations. However, one of the best known functions of the EJC is to promote mRNA surveillance through the nonsense-mediated mRNA decay pathway [66,67]. Many proteins have been described as EJC components, but the core of the complex is formed by four of them, Mago, 
Y14, eIF4AIII, and MLN51, which participate in most of the EJC functions [68]. Particularly, Y14 form a dimer with Mago that joins the two other proteins and participates in mRNA localization, nonsense-mediated mRNA decay, and intron-mediated enhancement in animals [69,70]. In plants, it is known that the EJC is required to regulate male gametophyte development [71] but its participation in the plant response to salt stress has not been clarified so far.

The orthologue of BvSATO6 in Arabidopsis, ATRBP45B, which possesses three RRM motifs, has been hypothesized to be involved in key aspects of RNA metabolism such as RNA stability [72]. It has been suggested that it could participate in stress signaling, but its roles in salt stress have not been studied either.

Finally, we identified two additional RBPs conferring tolerance upon expression in yeast, BvSATO1 and BvSATO2, which are analogs to each other. BvSATO1 and BvSATO2 are characterized by the presence of an arginine-glycine-glycine rich region (RGG), but they lack the consensus-sequence-motif RRM. In Arabidopsis, it was recently shown that AtRGGA, is a functional RBP required for a proper response to osmotic stress [39]. Thus, overexpression of AtRGGA in Arabidopsis improved the plant salt tolerance and Atrgga mutants were hypersensitive to salt stress during germination and during the vegetative stage [39]. In this work we have demonstrated that expression of the sugar beet BvSATO1 improves salt tolerance in Arabidopsis. Thus, it appears that SATO1 from different plant species could have a similar role under salt stress conditions. This role could be related to its participation in a signaling mechanism activated by salt stress, such as the ABA signal transduction pathway. In this respect, it was found that the StRGGA is induced by osmotic stress in potato and that ABA induces the Arabidopsis AtRGGA [39,40]. BvSATO1 and BvSATO2 were isolated from a salt induced sugar beet cDNA library. However, neither BvSATO1, BvSATO2 nor the Arabidopsis AtRGGA were induced by salt (this study, [39]). On the contrary, they were repressed by salt stress (this study, [39]). Thus, our results support the idea that, at least in the halotolerant sugar beet, BvSATO1 and BvSATO2 could be targets of salt toxicity rather than play a role in salt signaling. Accordingly, an increased amount of these proteins could ameliorate the salt toxicity as observed in the Arabidopsis expressing lines. The fact that BvSATO1 and BvSATO2 were the clones that were most often isolated in the yeast screening, even though they could be misrepresented in the $\mathrm{NaCl}$-induced cDNA library, reinforce our idea. Besides, BvSATO1 and BvSATO2 were not induced by ABA in the experimental conditions assayed, indicating that the beneficial effect of BvSATO1 under salt stress is not always related to an ABA dependent mechanism. In fact, BvSATO1 and BvSATO2 provide tolerance to yeast, where ABA signaling mechanism is not conserved, which would also support our hypothesis.

As with AtRGGA, BvSATO1 and BvSATO2 contain the Stm1 and HABP4_PAI-RBP1 domains found in other RBP from yeast and mammals, which have been suggested to be involved in the regulation of mRNA stability [73,74]. If BvSATO1 and BvSATO2 were located in the cytoplasm, as it has been demonstrated with the Arabidopsis AtRGGA, they could also be involved in posttranscriptional regulation mechanisms. If our hypothesis is correct, then the post-transcriptional mechanism in which BvSATO1 and BvSATO2 are involved could also be a target of salt toxicity in plants. In this respect, the fact that BvSATO1 expression in yeast did not increase expression of genes related with osmotic stress, as the splicing factor BvU2AF35b did, would support that these two proteins improve salt tolerance by two different mechanisms.

In summary, we identified six sugar beet RBP which increased yeast salt tolerance upon expression. Characterization of two Arabidopsis orthologues of the sugar beet SATO have already proven that proteins coded by these genes ameliorate salt stress in plants $[39,42]$. We have provided additional evidence indicating that expression of BvSATO1 improves salt tolerance in Arabidopsis. Then, our study validates the expression of plant cDNA libraries in yeast to identify bottle necks in stress tolerance in plants, and confirm that some mechanisms conferring salt tolerance are conserved in yeast and the plant kingdom. 


\section{Conclusions}

The tight regulation of RNA metabolic processes upon osmotic stress has been shown in yeast [58,75-78]. Our studies show that not only splicing but other processes related to RNA metabolism, such as RNA stability and nonsense-mediated mRNA decay could also be affected by salt toxicity. Therefore, we suggest that RNA metabolism in general could also be considered a target of salt toxicity in plants and that attempts to improve any of these processes may have a positive effect on crops survival under salt stress conditions. Our results should stimulate further studies to characterize the other genes identified in this study, to confirm their role in salt tolerance in plants, so that biotechnological approaches could be implemented to improve crop productivity under stress conditions.

Supplementary Materials: The following are available online at http://www.mdpi.com/2073-4395/10/2/250/s1, Figure S1: Southern blot analysis of the sugar beet genes coding for RNA binding proteins giving salt tolerance to yeast. Genomic DNA was digested with BamH I (B), Hind III (H) or EcoR I, was separated on 0.8\% agarose gel, transferred onto a nylon membrane and hybridized with a radiolabeled probe of the respective gene., Figure S2: Sodium tolerance phenotype of yeast mutants impaired in splicing when expressing the sugar beet RNA binding proteins BvSATO1 and BvU2AF35b. cus $2 \Delta$ and mud2 $\Delta$ mutants were transformed with either the empty vector (pYPGE15) or pYPGE15 containing the cDNA of BvSATO1 or BvU2AF35b. Transformed cells were tested for tolerance to sodium. Spots are yeast serial dilutions as described in materials and methods. Images of cells grown in control media (SC) were taken after two days of growth Images of cells grown in control media (SC) were taken after two days of growth. Images of cells grown in $1.5 \mathrm{M} \mathrm{NaCl}$ were taken seven days later.

Author Contributions: S.R.T., R.K. and C.C.B. performed the experiments and participated in the experimental design. R.S., P.A. and R.R. designed and supervised the experiments. R.R. wrote the manuscript. All authors have read and agreed to the published version of the manuscript.

Funding: This research was funded by the Spanish Government and the European Union (grant number FEDER/BFU2015-64204R to R.R., and BFU2016-77728-C3-3-P to P.A.), by the ERI BIOTECMED (ISIC/2013/004) and by the Valencian Government (APOSTD 2017/118).

Acknowledgments: We thank SCIE of the Universitat de València for technical assistance.

Conflicts of Interest: The authors declare no conflict of interest.

\section{References}

1. Munns, R.; Day, D.A.; Fricke, W.; Watt, M.; Arsova, B.; Barkla, B.J.; Bose, J.; Byrt, C.S.; Chen, Z.H.; Foster, K.J.; et al. Energy costs of salt tolerance in crop plants. New Phytol. 2019, 225, 1072-1090. [CrossRef] [PubMed]

2. Munns, R.; Tester, M. Mechanisms of salinity tolerance. Annu. Rev. Plant. Biol. 2008, 59, 651-681. [CrossRef] [PubMed]

3. Vinocur, B.; Altman, A. Recent advances in engineering plant tolerance to abiotic stress: Achievements and limitations. Curr. Opin. Biotechnol. 2005, 16, 123-132. [CrossRef] [PubMed]

4. Blumwald, E. Sodium transport and salt tolerance in plants. Curr. Opin. Cell Biol. 2000, 12, 431-434. [CrossRef]

5. Serrano, R. Salt tolerance in plants and microorganisms: Toxicity targets and defense responses. Int. Rev. Cytol. 1996, 165, 1-52.

6. Yamaguchi, T.; Blumwald, E. Developing salt-tolerant crop plants: Challenges and opportunities. Trends Plant Sci. 2005, 10, 615-620. [CrossRef]

7. Zhu, J.K. Salt and drought stress signal transduction in plants. Annu. Rev. Plant. Biol. 2002, 53, $247-273$. [CrossRef]

8. Hasegawa, P.M.; Bressan, R.A.; Zhu, J.K.; Bohnert, H.J. Plant Cellular and Molecular Responses to High Salinity. Annu. Rev. Plant Physiol. Plant Mol. Biol. 2000, 51, 463-499. [CrossRef]

9. Parida, A.K.; Das, A.B. Salt tolerance and salinity effects on plants: A review. Ecotoxicol. Environ. Saf. 2005, 60, 324-349. [CrossRef]

10. Guo, Y.; Qiu, Q.S.; Quintero, F.J.; Pardo, J.M.; Ohta, M.; Zhang, C.; Schumaker, K.S.; Zhu, J.K. Transgenic evaluation of activated mutant alleles of SOS2 reveals a critical requirement for its kinase activity and C-terminal regulatory domain for salt tolerance in Arabidopsis thaliana. Plant Cell 2004, 16, 435-449. [CrossRef] 
11. Shi, H.; Lee, B.H.; Wu, S.J.; Zhu, J.K. Overexpression of a plasma membrane Na+/H+ antiporter gene improves salt tolerance in Arabidopsis thaliana. Nat. Biotechnol. 2003, 21, 81-85. [CrossRef] [PubMed]

12. Zhu, J.K. Regulation of ion homeostasis under salt stress. Curr. Opin. Plant Biol. 2003, 6, 441-445. [CrossRef]

13. Batool, S.; Uslu, V.V.; Rajab, H.; Ahmad, N.; Waadt, R.; Geiger, D.; Malagoli, M.; Xiang, C.B.; Hedrich, R.; Rennenberg, H.; et al. Sulfate is Incorporated into Cysteine to Trigger ABA Production and Stomatal Closure. Plant Cell 2018, 30, 2973-2987. [CrossRef] [PubMed]

14. Fujii, H.; Chinnusamy, V.; Rodrigues, A.; Rubio, S.; Antoni, R.; Park, S.Y.; Cutler, S.R.; Sheen, J.; Rodriguez, P.L.; Zhu, J.K. In vitro reconstitution of an abscisic acid signalling pathway. Nature 2009, 462, 660-664. [CrossRef]

15. Geiger, D.; Scherzer, S.; Mumm, P.; Stange, A.; Marten, I.; Bauer, H.; Ache, P.; Matschi, S.; Liese, A.; Al-Rasheid, K.A.; et al. Activity of guard cell anion channel SLAC1 is controlled by drought-stress signaling kinase-phosphatase pair. Proc. Natl. Acad. Sci. USA 2009, 106, 21425-21430. [CrossRef]

16. Kang, J.Y.; Choi, H.I.; Im, M.Y.; Kim, S.Y. Arabidopsis basic leucine zipper proteins that mediate stress-responsive abscisic acid signaling. Plant Cell 2002, 14, 343-357. [CrossRef]

17. Nakashima, K.; Shinwari, Z.K.; Sakuma, Y.; Seki, M.; Miura, S.; Shinozaki, K.; Yamaguchi-Shinozaki, K. Organization and expression of two Arabidopsis DREB2 genes encoding DRE-binding proteins involved in dehydration- and high-salinity-responsive gene expression. Plant Mol. Biol. 2000, 42, 657-665. [CrossRef]

18. Park, S.Y.; Fung, P.; Nishimura, N.; Jensen, D.R.; Fujii, H.; Zhao, Y.; Lumba, S.; Santiago, J.; Rodrigues, A.; Chow, T.F.; et al. Abscisic acid inhibits type 2C protein phosphatases via the PYR/PYL family of START proteins. Science 2009, 324, 1068-1071. [CrossRef]

19. Apse, M.P.; Aharon, G.S.; Snedden, W.A.; Blumwald, E. Salt tolerance conferred by overexpression of a vacuolar $\mathrm{Na}+\mathrm{H}+$ antiport in Arabidopsis. Science 1999, 285, 1256-1258. [CrossRef]

20. Ren, Z.H.; Gao, J.P.; Li, L.G.; Cai, X.L.; Huang, W.; Chao, D.Y.; Zhu, M.Z.; Wang, Z.Y.; Luan, S.; Lin, H.X. A rice quantitative trait locus for salt tolerance encodes a sodium transporter. Nat. Genet. 2005, 37, 1141-1146. [CrossRef]

21. Sakamoto, H.; Maruyama, K.; Sakuma, Y.; Meshi, T.; Iwabuchi, M.; Shinozaki, K.; Yamaguchi-Shinozaki, K. Arabidopsis Cys2/His2-type zinc-finger proteins function as transcription repressors under drought, cold, and high-salinity stress conditions. Plant Physiol. 2004, 136, 2734-2746. [CrossRef] [PubMed]

22. Taji, T.; Ohsumi, C.; Iuchi, S.; Seki, M.; Kasuga, M.; Kobayashi, M.; Yamaguchi-Shinozaki, K.; Shinozaki, K. Important roles of drought- and cold-inducible genes for galactinol synthase in stress tolerance in Arabidopsis thaliana. Plant J. 2002, 29, 417-426. [CrossRef] [PubMed]

23. Urao, T.; Yamaguchi-Shinozaki, K.; Shinozaki, K. Two-component systems in plant signal transduction. Trends Plant Sci. 2000, 5, 67-74. [CrossRef]

24. Yoo, J.H.; Park, C.Y.; Kim, J.C.; Heo, W.D.; Cheong, M.S.; Park, H.C.; Kim, M.C.; Moon, B.C.; Choi, M.S.; Kang, Y.H.; et al. Direct interaction of a divergent CaM isoform and the transcription factor, MYB2, enhances salt tolerance in arabidopsis. J. Biol. Chem. 2005, 280, 3697-3706. [CrossRef] [PubMed]

25. Fabregas, N.; Lozano-Elena, F.; Blasco-Escamez, D.; Tohge, T.; Martinez-Andujar, C.; Albacete, A.; Osorio, S.; Bustamante, M.; Riechmann, J.L.; Nomura, T.; et al. Overexpression of the vascular brassinosteroid receptor BRL3 confers drought resistance without penalizing plant growth. Nat. Commun. 2018, 9, 4680. [CrossRef]

26. Takagi, H.; Tamiru, M.; Abe, A.; Yoshida, K.; Uemura, A.; Yaegashi, H.; Obara, T.; Oikawa, K.; Utsushi, H.; Kanzaki, E.; et al. MutMap accelerates breeding of a salt-tolerant rice cultivar. Nat. Biotechnol. 2015, 33, 445-449. [CrossRef]

27. Zhang, J.Z.; Creelman, R.A.; Zhu, J.K. From laboratory to field. Using information from Arabidopsis to engineer salt, cold, and drought tolerance in crops. Plant Physiol. 2004, 135, 615-621. [CrossRef]

28. Zhang, M.; Cao, Y.; Wang, Z.; Wang, Z.Q.; Shi, J.; Liang, X.; Song, W.; Chen, Q.; Lai, J.; Jiang, C. A retrotransposon in an HKT1 family sodium transporter causes variation of leaf $\mathrm{Na}(+)$ exclusion and salt tolerance in maize. New Phytol. 2018, 217, 1161-1176. [CrossRef]

29. Greenway, H.; Munns, R. Mechanisms of salt tolerance in nonhalophytes. Annu. Rev. Plant Physiol. 1980, 31, 149-190. [CrossRef]

30. Kanhonou, R.; Serrano, R.; Palau, R.R. A catalytic subunit of the sugar beet protein kinase CK2 is induced by salt stress and increases $\mathrm{NaCl}$ tolerance in Saccharomyces cerevisiae. Plant Mol. Biol. 2001, 47, 571-579. [CrossRef] 
31. Rausell, A.; Kanhonou, R.; Yenush, L.; Serrano, R.; Ros, R. The translation initiation factor eIF1A is an important determinant in the tolerance to $\mathrm{NaCl}$ stress in yeast and plants. Plant J. 2003, 34, 257-267. [CrossRef] [PubMed]

32. Serrano, R.; Gaxiola, R.; Rios, G.; Forment, J.; Vicente, O.; Ros, R. Salt stress proteins identified by a functional approach in yeast. Chem. Mon. 2003, 134, 1445-1464. [CrossRef]

33. Fedoroff, N.V. RNA-binding proteins in plants: The tip of an iceberg? Curr. Opin. Plant Biol. 2002, 5, 452-459. [CrossRef]

34. Lorkovic, Z.J. Role of plant RNA-binding proteins in development, stress response and genome organization. Trends Plant Sci. 2009, 14, 229-236. [CrossRef] [PubMed]

35. Albà, M.M.; Pagès, M. Plant proteins containing the RNA-recognition motif. Trends Plant Sci. 1998, 3, $15-21$. [CrossRef]

36. Burd, C.G.; Dreyfuss, G. Conserved structures and diversity of functions of RNA-binding proteins. Science 1994, 265, 615-621. [CrossRef] [PubMed]

37. Lorkovic, Z.J.; Barta, A. Genome analysis: RNA recognition motif (RRM) and K homology (KH) domain RNA-binding proteins from the flowering plant Arabidopsis thaliana. Nucleic Acids Res. 2002, 30, 623-635. [CrossRef]

38. Nakaminami, K.; Matsui, A.; Shinozaki, K.; Seki, M. RNA regulation in plant abiotic stress responses. Biochim. Biophys. Acta 2012, 1819, 149-153. [CrossRef]

39. Ambrosone, A.; Batelli, G.; Nurcato, R.; Aurilia, V.; Punzo, P.; Bangarusamy, D.K.; Ruberti, I.; Sassi, M.; Leone, A.; Costa, A.; et al. The Arabidopsis RNA-binding protein AtRGGA regulates tolerance to salt and drought stress. Plant Physiol. 2015, 168, 292-306. [CrossRef]

40. Ambrosone, A.; Costa, A.; Leone, A.; Grillo, S. Beyond transcription: RNA-binding proteins as emerging regulators of plant response to environmental constraints. Plant Sci. 2012, 182, 12-18. [CrossRef]

41. Ambrosone, A.; Costa, A.; Martinelli, R.; Massarelli, I.; de Simone, V.; Grillo, S.; Leone, A. Differential gene regulation in potato cells and plants upon abrupt or gradual exposure to water stress. Acta Physiol. Plantatrum 2011, 33, 1157-1171. [CrossRef]

42. Amorim, M.d.; Willing, E.M.; Szabo, E.X.; Francisco-Mangilet, A.G.; Droste-Borel, I.; Macek, B.; Schneeberger, K.; Laubinger, S. The U1 snRNP Subunit LUC7 Modulates Plant Development and Stress Responses via Regulation of Alternative Splicing. Plant Cell 2018, 30, 2838-2854. [CrossRef]

43. Sorenson, R.; Bailey-Serres, J. Selective mRNA sequestration by OLIGOURIDYLATE-BINDING PROTEIN 1 contributes to translational control during hypoxia in Arabidopsis. Proc. Natl. Acad. Sci. USA 2014, 111, 2373-2378. [CrossRef]

44. Frey, N.F.d.; Muller, P.; Jammes, F.; Kizis, D.; Leung, J.; Perrot-Rechenmann, C.; Bianchi, M.W. The RNA binding protein Tudor-SN is essential for stress tolerance and stabilizes levels of stress-responsive mRNAs encoding secreted proteins in Arabidopsis. Plant Cell 2010, 22, 1575-1591. [CrossRef]

45. Forment, J.; Naranjo, M.A.; Roldan, M.; Serrano, R.; Vicente, O. Expression of Arabidopsis SR-like splicing proteins confers salt tolerance to yeast and transgenic plants. Plant J. 2002, 30, 511-519. [CrossRef]

46. Gu, J.; Xia, Z.; Luo, Y.; Jiang, X.; Qian, B.; Xie, H.; Zhu, J.K.; Xiong, L.; Zhu, J.; Wang, Z.Y. Spliceosomal protein $\mathrm{U} 1 \mathrm{~A}$ is involved in alternative splicing and salt stress tolerance in Arabidopsis thaliana. Nucleic Acids Res. 2018, 46, 1777-1792. [CrossRef] [PubMed]

47. Kim, J.S.; Jung, H.J.; Lee, H.J.; Kim, K.A.; Goh, C.H.; Woo, Y.; Oh, S.H.; Han, Y.S.; Kang, H. Glycine-rich RNA-binding protein 7 affects abiotic stress responses by regulating stomata opening and closing in Arabidopsis thaliana. Plant J. 2008, 55, 455-466. [CrossRef] [PubMed]

48. Wallis, J.W.; Chrebet, G.; Brodsky, G.; Rolfe, M.; Rothstein, R. A hyperrecombintion mutation in S. cerevisiae identifies a novel eukaryotic topoisomerase. Cell 1989, 58, 409-419. [CrossRef]

49. Banuelos, M.A.; Sychrova, H.; Bleykasten-Grosshans, C.; Souciet, J.L.; Potier, S. The Nha1 antiporter of Saccharomyces cerevisiae mediates sodium and potassium efflux. Microbiology 1998, 144 Pt 10, 2749-2758.

50. Garciadeblas, B.; Rubio, F.; Quintero, F.J.; Banuelos, M.A.; Haro, R.; Rodriguez-Navarro, A. Differential expression of two genes encoding isoforms of the ATPase involved in sodium efflux in Saccharomyces cerevisiae. Mol. Gen. Genet. 1993, 236, 363-368. [CrossRef]

51. Brachmann, C.B.; Davies, A.; Cost, G.J.; Caputo, E.; Li, J.; Hieter, P.; Boeke, J.D. Designer Deletion Strains derived from Saccharomyces cerevisiae S288C: A Useful set of Strains and Plasmids for PCR-mediated Gene Disruption and Other Applications. Yeast 1998, 14, 115-132. [CrossRef] 
52. Gil-Mascarell, R.; Lopez-Coronado, J.M.; Belles, J.M.; Serrano, R.; Rodriguez, P.L. The Arabidopsis HAL2-like gene family includes a novel sodium-sensitive phosphatase. Plant J. 1999, 17, 373-383. [CrossRef] [PubMed]

53. Brunelli, J.P.; Pall, M.L. A series of yeast/Escherichia coli lambda expression vectors designed for directional cloning of cDNAs and cre/lox-mediated plasmid excision. Yeast 1993, 9, 1309-1318. [CrossRef] [PubMed]

54. Gietz, D.; Jean, A.S.; Woods, R.A.; Schiestl, R.H. Improved method for high efficiency transformation of intact yeast cells. Nucleic Acids Res. 1992, 20, 1425. [CrossRef] [PubMed]

55. Bevan, M. Binary Agrobacterium vectors for plant transformation. Nucleic Acids Res. 1984, 12, 8711-8721. [CrossRef] [PubMed]

56. Deblaere, R.; Bytebier, B.; de Greve, H.; Deboeck, F.; Schell, J.; van Montagu, M.; Leemans, J. Efficient octopine Ti plasmid-derived vectors for Agrobacterium-mediated gene transfer to plants. Nucleic Acids Res. 1985, 13, 4777-4788. [CrossRef]

57. Clough, S.J.; Bent, A.F. Floral dip: A simplified method for Agrobacterium-mediated transformation of Arabidopsis thaliana. Plant J. 1998, 16, 735-743. [CrossRef]

58. Garre, E.; Romero-Santacreu, L.; Barneo-Munoz, M.; Miguel, A.; Perez-Ortin, J.E.; Alepuz, P. Nonsense-mediated mRNA decay controls the changes in yeast ribosomal protein pre-mRNAs levels upon osmotic stress. PLoS ONE 2013, 8, e61240. [CrossRef]

59. Wang, B.B.; Brendel, V. Molecular characterization and phylogeny of U2AF35 homologs in plants. Plant Physiol. 2006, 140, 624-636. [CrossRef]

60. Dohm, J.C.; Minoche, A.E.; Holtgrawe, D.; Capella-Gutierrez, S.; Zakrzewski, F.; Tafer, H.; Rupp, O.; Sorensen, T.R.; Stracke, R.; Reinhardt, R.; et al. The genome of the recently domesticated crop plant sugar beet (Beta vulgaris). Nature 2014, 505, 546-549. [CrossRef]

61. Berglund, J.A.; Chua, K.; Abovich, N.; Reed, R.; Rosbash, M. The splicing factor BBP interacts specifically with the pre-mRNA branchpoint sequence UACUAAC. Cell 1997, 89, 781-787. [CrossRef]

62. Wang, Q.; Zhang, L.; Lynn, B.; Rymond, B.C. A BBP-Mud2p heterodimer mediates branchpoint recognition and influences splicing substrate abundance in budding yeast. Nucleic Acids Res. 2008, 36, 2787-2798. [CrossRef] [PubMed]

63. Simpson, G.G.; Clark, G.P.; Rothnie, H.M.; Boelens, W.; van Venrooij, W.; Brown, J.W. Molecular characterization of the spliceosomal proteins U1A and U2B" from higher plants. EMBO J. 1995, 14, 4540-4550. [CrossRef] [PubMed]

64. Xiong, F.; Ren, J.J.; Yu, Q.; Wang, Y.Y.; Lu, C.C.; Kong, L.J.; Otegui, M.S.; Wang, X.L. AtU2AF65b functions in abscisic acid mediated flowering via regulating the precursor messenger RNA splicing of ABI5 and FLC in Arabidopsis. New Phytol. 2019, 223, 277-292. [CrossRef]

65. Mufarrege, E.F.; Gonzalez, D.H.; Curi, G.C. Functional interconnections of Arabidopsis exon junction complex proteins and genes at multiple steps of gene expression. J. Exp. Bot. 2011, 62, 5025-5036. [CrossRef] [PubMed]

66. Boehm, V.; Gehring, N.H. Exon Junction Complexes: Supervising the Gene Expression Assembly Line. Trends Genet. 2016, 32, 724-735. [CrossRef]

67. Chang, Y.F.; Imam, J.S.; Wilkinson, M.F. The nonsense-mediated decay RNA surveillance pathway. Annu. Rev. Biochem. 2007, 76, 51-74. [CrossRef]

68. Tange, T.O.; Shibuya, T.; Jurica, M.S.; Moore, M.J. Biochemical analysis of the EJC reveals two new factors and a stable tetrameric protein core. RNA 2005, 11, 1869-1883. [CrossRef]

69. Dostie, J.; Dreyfuss, G. Translation is required to remove Y14 from mRNAs in the cytoplasm. Curr. Biol. 2002, 12, 1060-1067. [CrossRef]

70. Shi, H.; Xu, R.M. Crystal structure of the Drosophila Mago nashi-Y14 complex. Genes Dev. 2003, 17, $971-976$. [CrossRef]

71. Cilano, K.; Mazanek, Z.; Khan, M.; Metcalfe, S.; Zhang, X.N. A New Mutation, hap1-2, Reveals a C Terminal Domain Function in AtMago Protein and Its Biological Effects in Male Gametophyte Development in Arabidopsis thaliana. PLOS ONE 2016, 11, e0148200. [CrossRef] [PubMed]

72. Muthuramalingam, M.; Wang, Y.; Li, Y.; Mahalingam, R. Interacting protein partners of Arabidopsis RNA-binding protein AtRBP45b. Plant Biol. 2017, 19, 327-334. [CrossRef] [PubMed]

73. Heaton, J.H.; Dlakic, W.M.; Dlakic, M.; Gelehrter, T.D. Identification and cDNA cloning of a novel RNA-binding protein that interacts with the cyclic nucleotide-responsive sequence in the Type-1 plasminogen activator inhibitor mRNA. J. Biol. Chem. 2001, 276, 3341-3347. [CrossRef] [PubMed] 
74. Huang, L.; Grammatikakis, N.; Yoneda, M.; Banerjee, S.D.; Toole, B.P. Molecular characterization of a novel intracellular hyaluronan-binding protein. J. Biol. Chem. 2000, 275, 29829-29839. [CrossRef]

75. Garre, E.; Pelechano, V.; del Pino, M.S.; Alepuz, P.; Sunnerhagen, P. The Lsm1-7/Pat1 complex binds to stress-activated mRNAs and modulates the response to hyperosmotic shock. PLoS Genet. 2018, 14, e1007563. [CrossRef]

76. Garre, E.; Romero-Santacreu, L.; de Clercq, N.; Blasco-Angulo, N.; Sunnerhagen, P.; Alepuz, P. Yeast mRNA cap-binding protein $\mathrm{Cbc1/Sto1}$ is necessary for the rapid reprogramming of translation after hyperosmotic shock. Mol. Biol. Cell 2012, 23, 137-150. [CrossRef]

77. Romero-Santacreu, L.; Moreno, J.; Perez-Ortin, J.E.; Alepuz, P. Specific and global regulation of mRNA stability during osmotic stress in Saccharomyces cerevisiae. RNA 2009, 15, 1110-1120. [CrossRef]

78. Canadell, D.; Garcia-Martinez, J.; Alepuz, P.; Perez-Ortin, J.E.; Arino, J. Impact of high pH stress on yeast gene expression: A comprehensive analysis of mRNA turnover during stress responses. Biochim. Biophys. Acta 2015, 1849, 653-664. [CrossRef]

(C) 2020 by the authors. Licensee MDPI, Basel, Switzerland. This article is an open access article distributed under the terms and conditions of the Creative Commons Attribution (CC BY) license (http://creativecommons.org/licenses/by/4.0/). 